\title{
Effect of vacuum storage on shelf life of a grain protector based on Peumus boldus Molina foliage powder and lime against Sitophilus zeamais Motschulsky
}

\author{
Paulina Rivera $^{1}$, Gonzalo Silva ${ }^{1 *}$, Inés Figueroa1, Maritza Tapia ${ }^{1}$, and J. Concepción Rodríguez²
}

\begin{abstract}
The maize weevil (Sitophilus zeamais Motschulsky, Coleoptera: Curculionidae) is a key pest of stored grain maize. As an ecological pest control alternative, the use of botanical insecticides, such as powder from boldus (Peumus boldus Molina) foliage singly or mixed with lime, has been evaluated. Unfortunately, its shelf life is very short and does not exceed $15 \mathrm{~d}$. The effectiveness of vacuum storage on insecticidal properties of a natural grain protector produced with boldus powder:lime at proportions of 50:50 and 60:40 against adults of $S$. zeamais was assessed under laboratory conditions. Treatments were evaluated at $1 \%$ and $2 \%(\mathrm{w} / \mathrm{w})$ for $150 \mathrm{~d}$ of storage. All treatments based on boldus powder kept the level of mortality by contact activity over $80 \%$ at $150 \mathrm{~d}$ of storage. The highest toxicity, as a fumigant, was observed in treatments $50: 50$ at $2 \%$ and $60: 40$ at $1 \%$ and $2 \%$ with mortality over $60 \%$. The grain weight loss was less than $1 \%$ and seed germination was not affected. With the exception of 0:100 at $2 \%$ without vacuum storage, all treatments were repellent to S. zeamais. Vacuum storage extended shelf life of the grain protector for $150 \mathrm{~d}$.
\end{abstract}

Key words: Botanical insecticides, contact toxicity, fumigant, maize weevil, repellent.

\section{INTRODUCTION}

Cereals are a very relevant part of the human and animal diet (FAO, 1993). Annually, insect pests of stored products cause losses of approximately $30 \%$ although in developing countries this impact reaches up to $50 \%$ (García-Lara et al., 2004). Insect pests of stored grains are mainly controlled by synthetic contact insecticides, such as organophosphates or pyrethroids, and fumigants, such as methyl bromide and aluminum phosphide. However, the use of synthetic insecticides has disadvantages such as toxic residues, human intoxication, environmental pollution, and the development of insecticide resistance (White and Leesch, 1966). Additionally, the use of methyl bromide is banned because it depletes the ozone layer (USDA, 2000).

The maize weevil (Sitophilus zeamais Motschulsky, Coleoptera: Curculionidae) is considered to be a severe worldwide pest of stored products. The attack of this insect species begins in the field and continues once the grain is stored. It may cause complete grain destruction in only 6 mo. The larvae and adult feed on the endosperm, which leads to the attack of secondary insect pests

\footnotetext{
${ }^{1}$ Universidad de Concepción, Facultad de Agronomía, Av. Vicente Méndez 595, Chillán, Chile.

"Corresponding author (gosilva@udec.cl).

${ }^{2}$ Colegio de Postgraduados, Campus Montecillo, km 36,5 Carretera

México-Texcoco, Montecillo, Estado de México, México.

Received: 2 September 2013.

Accepted: 14 January 2014.

doi:10.4067/S0718-58392014000100008
}

and fungi (Larraín, 1994). It is usually controlled by synthetic insecticides with the consequent development of resistance as it has occurred with phosphine (Pimentel et al., 2009), organophosphates (Pereira et al., 2009), and pyrethroids (Ribeiro et al., 2003). According to the arthropod pesticide resistance database (www. pesticideresistance.org), S. zeamais has 32 cases of field resistance reported for the carbaryl, chlorpyrifosmethyl, cypermethrin, DDT, deltamethrin, $\mathrm{HCH}$-gamma, malathion, phosphine, and permethrin insecticides. Hence, the use of botanical insecticides should be considered as a viable alternative. Malik and Mujtaba (1984) and Makanjuola (1989) indicated that these pesticides have shown contact, fumigant, antifeedant, and repellent insect activity. According to Weaver and Subramanyam (2000), botanical insecticides against stored grain pests are used as a dry vegetable powder mixed with the grain.

The perennial boldus tree, Peumus boldus Molina (Monimiaceae), is native to Chile and its powder has insecticidal activity against $S$. zeamais (Páez et al., 1990; Silva et al., 2003a; 2005; Pérez et al., 2007), and third instar larvae of Spodoptera littoralis Boisduval (Lepidoptera: Noctuidae) (Zapata et al., 2006), Spodoptera frugiperda J.E. Smith (Lepidoptera: Noctuidae), and Helicoverpa zea (Boddie) (Lepidoptera: Noctuidae) (Silva-Aguayo et al., 2010). The efficacy of botanical insecticides is usually accomplished by mixing them with mineral compounds such as lime or calcium carbonate. Silva et al. (2003a; 2005) and Nuñez et al. (2010) indicated that ratios of 50:50 and 60:40 (boldo powder:lime) at concentrations of $1.0 \%$ and $2.0 \%(\mathrm{w} / \mathrm{w})$ caused $95 \%$ mortality of S. zeamais. However, Bustos-Figueroa et al. (2009) observed that the 
toxicity of $P$. boldus powder mixed with lime decreases after $30 \mathrm{~d}$ of storage. Pizarro et al. (2013) indicated that boldus powder stored under refrigerated conditions does not exceed $65 \%$ mortality after $15 \mathrm{~d}$. This impact of storage on biological efficacy limits the commercial use of this type of pesticide. The aim of this research was to evaluate the effect of storage under vacuum conditions on the contact, fumigant, and repellent activity against $S$. zeamais of a natural grain protector elaborated with a mixture of $P$. boldus foliage powder and lime.

\section{MATERIALS AND METHODS}

The study was carried out from December 2012 to April 2013 in the Laboratory of Entomology, Faculty of Agronomy, Universidad de Concepción in Chillan, Biobío Region, Chile. Bioassays using boldus powder alone or mixed with lime stored under and without vacuum conditions at eight storage times against $S$. zeamais were assessed.

Plant material and grains. Peumus boldus foliage was collected in Pinto ( $36^{\circ} 42^{\prime} \mathrm{S}, 71^{\circ} 54^{\prime} \mathrm{W}, 286 \mathrm{~m}$ a.s.1.), province of Nuble, Biobío Region, Chile, with criteria used by Vogel et al. (1997). Once collected, leaves were dried for $48 \mathrm{~h}$ in a stove (UNB 500, Memmert Gmbh, Schwabach, Germany) at $40{ }^{\circ} \mathrm{C}$. After that, foliage was ground in an electric coffee grinder (Moulinex, A5052HF, Alençon, France) to obtain a fine powder with a 20 mesh (0.841 mm) sieve (Dual Manufacturing, Chicago, Illinois, USA).

Maize grains with $14 \%$ moisture were used as food substrate. The maize was obtained in the local market. To avoid any prior infestation, grains were washed and frozen at $-4 \pm 1{ }^{\circ} \mathrm{C}$ for $48 \mathrm{~h}$.

Insects. The insects used for the bioassays are susceptible to insecticides and were obtained from the Laboratory of Entomology, Faculty of Agronomy, Universidad de Concepción in Chillan. They were reproduced in $1 \mathrm{~L}$ glass flasks containing maize as a food source. Insects were maintained in total darkness at $30 \pm 1{ }^{\circ} \mathrm{C}$ and $60 \%$ $\mathrm{RH}$ in a bioclimatic chamber (IPS 749, Memmert Gmbh, Schwabach, Germany).

Treatments. We used boldus foliage powder:lime mixture at two proportions of 50:50 and 60:40. According to Silva et al. (2006), these ratios are the most effective against $S$. zeamais. The boldus powder and lime were also assessed separately. Treatments were set up in transparent plastic bags (Oster Rol20, Sunbeam Products, Miami, Florida, USA). One set was stored under vacuum conditions using a food vacuum sealer machine (Oster FoodSaver V2240, Sunbeam Products); the other was kept without vacuum conditions. Both types of treatments (under and without vacuum conditions) were stored in a paperboard box to simulate warehouse conditions at room temperature (20 $\pm 5^{\circ} \mathrm{C}$ ). Eight storage times were assessed: $0,7,15,30$, $60,90,120$, and $150 \mathrm{~d}$. All treatments were evaluated at concentrations of $1.0 \%$ and $2.0 \%(\mathrm{w} / \mathrm{w})$ (Nuñez et al., 2010). After the respective storage time, the insecticidal effect of each treatment was evaluated.

Contact toxicity. These bioassays were carried out using the methodology by Silva et al. (2006) where $100 \mathrm{~g}$ maize grains were placed into $250 \mathrm{~mL}$ jars, the respective treatment was added, and the container was hand shaken for $1 \mathrm{~min}$. After that, 20 insect couples, not older than $10 \mathrm{~d}$, were added. The untreated control was a jar with $100 \mathrm{~g}$ maize grains infested with 20 insects. The sex was determined using the criteria proposed by Halstead (1963). After insect infestation, containers were transferred to a bioclimatic chamber $\left(25 \pm 1^{\circ} \mathrm{C}, 60 \% \mathrm{RH}\right)$.

Adult mortality. The percentage of mortality was assessed $7 \mathrm{~d}$ after infestation (DAI). To consider the bioassay as valid, the maximum level of mortality accepted for the untreated control was $10 \%$; in cases when insects dying of natural causes in the control were lower than the threshold, mortality was corrected by Abbott's formula (Abbott, 1925), but if the control exceeded $10 \%$ mortality, the complete bioassay was discarded and repeated. An insect was considered dead when it failed to move after being prodded gently with a needle for $30 \mathrm{~s}$. After collecting the data, all the insects were removed and the flasks returned to the bioclimatic chamber.

$F_{1}$ adult emergence. After $55 \mathrm{DAI}$, the number of $\mathrm{F}_{1}$ adults was recorded and percentage emergence was calculated by considering the values of the untreated control as $100 \%$.

Grain weight loss and germination. Both variables were assessed 55 DAI. Grain weight loss was determined based on the difference between initial (100 g) and final grain weight. So as not to take into account grain weight reduced by moisture loss, the bioassay included four jars with $100 \mathrm{~g}$ maize without insects and at 55 DAI the weight difference was recorded and discounted from the cereal weight loss recorded in jars infested with $S$. zeamais. The impact of the treatments on maize germination was evaluated by selecting 10 apparently healthy seeds per treatment, which were germinated for $7 \mathrm{~d}$ on wet filter paper and kept under conditions of $24 \pm 2{ }^{\circ} \mathrm{C}$ and 60 $\pm 5 \% \mathrm{RH}$ in a bioclimatic chamber. The grains used in the bioassays were not certified seeds; hence, relative germination was estimated by considering the untreated control as $100 \%$.

Repellent effect. The methodology proposed by Mazzonetto and Vendramim (2003) was used with slight modifications. The experimental unit was a plastic 
Petri dish (5 $\mathrm{cm}$ diameter) containing $20 \mathrm{~g}$ maize grains mixed with the respective treatment. Treatments were intercalated on a Petri dish without powder (untreated control) in a circle around a central Petri dish containing 20 individuals of $S$. zeamais $48 \mathrm{~h}$ of age without sexing. The central Petri dish was connected to the treatments through tubes $10 \mathrm{~cm}$ long and $0.5 \mathrm{~cm}$ in diameter (Procópio et al., 2003). The experimental batch was maintained in a bioclimatic chamber for $24 \mathrm{~h}$ at $30 \pm 1{ }^{\circ} \mathrm{C}$. Subsequently, the number of insects present in each treatment was counted. Each treatment had 10 replicates and in each replicate the treatment locations were randomly rotated to avoid external interference. The repellency index was calculated according to Mazzonetto and Vendramim (2003), who classified powder as neutral if the index $=1$, attracting if $>1$, and repellent if $<1$.

Fumigant effect. The methodology to evaluate the fumigant effect was adapted from Tavares and Vendramim (2005). At the bottom of $200 \mathrm{~mL}$ plastic containers, a PVC tube, $5 \mathrm{~cm}$ long and $2.5 \mathrm{~cm}$ in diameter and containing the respective treatment, was inserted vertically. Then, PVC tubes were covered with a piece of fine organza fabric to prevent the direct contact of insects with the powder, but allowing release of volatile compounds into the environment. Outside, the tube and the inner edge of the plastic containers were filled with $20 \mathrm{~g}$ of maize, which were infested with 20 unsexed insects. The controls were plastic containers with $20 \mathrm{~g}$ maize grains infested with 20 insects without powder in the tube. Mortality by the fumigant effect was evaluated 5 DAI and each treatment included five replicates.

Experimental design and statistical analysis. We used a completely randomized experimental design with a factorial arrangement of $2 \times 8$ with two types of storage (under and without vacuum conditions) and eight treatments (four formulations 50:50, 60:40, 100:0, and $0: 100$ at concentrations of $1 \%$ and $2 \%$ ) during a storage period of $150 \mathrm{~d}$. Each treatment had four replicates and the percentage of mortality by contact toxicity and fumigant effect, emergence $\left(F_{1}\right)$, and germination were transformed with the equation arcsine $(\mathrm{x})^{1 / 2}$, while grain weight loss was transformed to the function $(\mathrm{x}+0.5)^{1 / 2}$ prior to ANOVA $(\alpha$ $=0.05)$ with the statistical software InfoStat ${ }^{\circledR}($ Balzarini et al., 2008). Statistical differences were determined by Tukey's test $(\mathrm{p} \leq 0.05)$.

\section{RESULTS AND DISCUSSION}

The assessed treatments produced with $P$. boldus powder and stored under vacuum conditions were effective after $150 \mathrm{~d}$ storage (Figures 1 and 2). The interaction between treatment factors and type of storage was significant $(\mathrm{p} \leq$ 0.05 ) for the variables of contact toxicity, emergence of adult insects $\left(\mathrm{F}_{1}\right)$, and fumigant effect (Table 1).
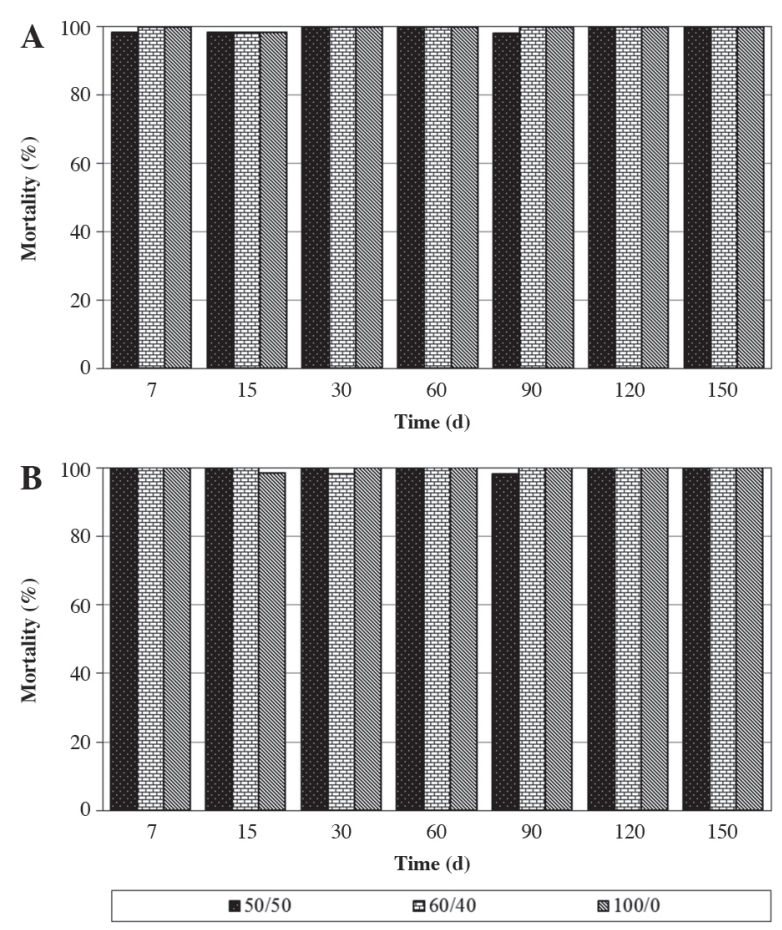

Figure 1. Mortality of Sitophilus zeamais exposed to Peumus boldus powder mixed with lime at different proportions (boldus:lime): 50:50, 60:40, and 100:0 at concentrations of 1.0\% (A) and $2.0 \%$ (B) stored under vacuum conditions for $150 \mathrm{~d}$.
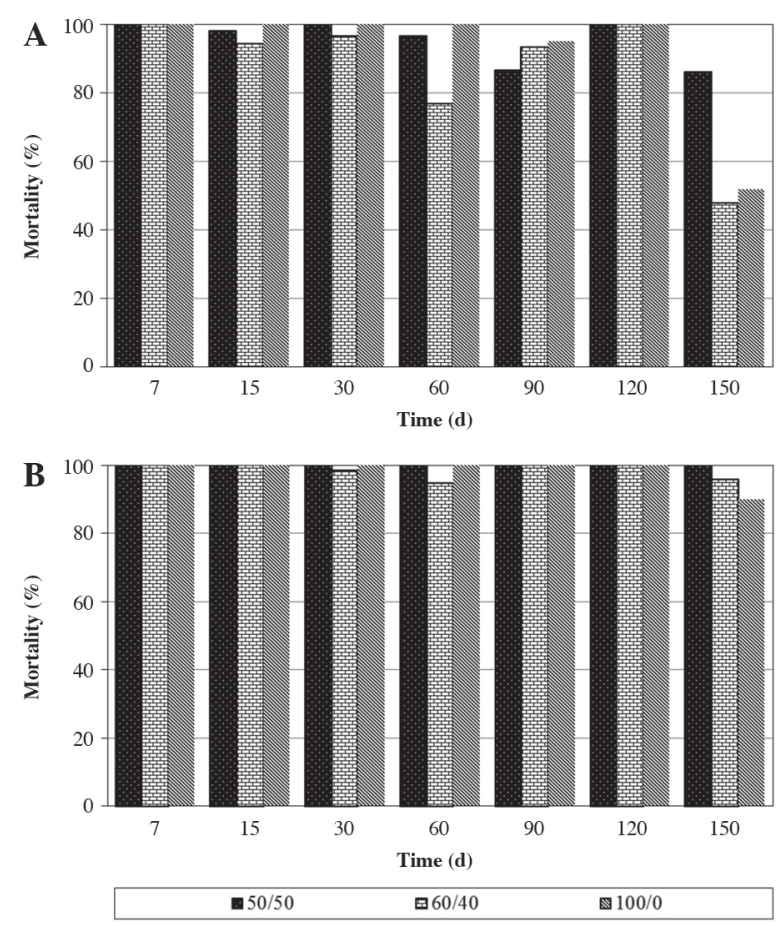

Figure 2. Mortality of Sitophilus zeamais exposed to Peumus boldus powder mixed with lime at different proportions (boldus:lime): $50: 50,60: 40$, and 100:0 at concentrations of $1.0 \%$ (A) and $2.0 \%$ (B) stored without vacuum conditions for $150 \mathrm{~d}$. 
Table 1. Mean minimum squares and coefficient of variation for assessed variables in the evaluation of biological activity of Peumus boldus powder singly and mixed with lime at proportions of 0:100, 50:50, 60:40, and 100:0 at concentrations of $1 \%$ and $2 \%(w / w)$ stored under environmental and vacuum conditions for $150 \mathrm{~d}$.

\begin{tabular}{lrrrrrr}
\hline Sources of variation & DF & MC & F $_{1}$ & GG & FE & GWL \\
\hline Treatment & 7 & $0.41^{*}$ & $0.90^{*}$ & 0.01 & $0.46^{*}$ & 0.15 \\
Package & 1 & $1.60^{*}$ & $1.61^{*}$ & 0.05 & $4.18^{*}$ & 0.01 \\
Treatment $\times$ Package & 7 & $0.12^{*}$ & $0.42^{*}$ & 0.02 & $0.29^{*}$ & 0.03 \\
Error & 32 & 0.02 & 0.11 & 0.01 & 0.02 & 0.06 \\
CV $\%$ & & 10.21 & 75.25 & 7.97 & 43.60 & 23.07
\end{tabular}

'Significant according to Tukey's test $(\mathrm{P} \leq 0.05)$.

CV: Coefficient of variation; DF: degree of freedom; MC: mortality by contact; $\mathrm{F}_{1}$ : emergence; $\mathrm{GG}$ : grain germination; FE: fumigant effect; GWL: grain weight loss

\section{Contact toxity}

Adult mortality. Peumus boldus mixed with lime and stored under vacuum conditions induced $100 \%$ mortality (Table 2); therefore, vacuum storage increases the time that the formulation remains toxic. Treatments without vacuum conditions exhibited better results that those observed by Silva et al. (2005) and Bustos-Figueroa et al. (2009), who indicated that $P$. boldus powder does not have a residual effect beyond $30 \mathrm{~d}$ of storage. This difference may be due to the type of container used. We used special bags for vacuum storage, while other authors used paper bags or opaque plastic containers allowing greater gas exchange. However, lime used alone under vacuum conditions was the only treatment that did not reach $100 \%$ mortality. Similar results were documented by Bustos-Figueroa et al. (2009) and Nuñez et al. (2010), but our results are better than those found by Silva et al. (2004), who did not exceed $60 \%$ mortality of S. zeamais treated with lime.

Adult insect emergence $\left(\mathbf{F}_{1}\right)$. The only treatment that showed significant differences $(\mathrm{p} \leq 0.05)$ with its counterpart was lime alone at $2.0 \%$, which showed $\mathrm{F}_{1}$ emergence of $11.1 \%$ and $98.8 \%$ under and without vacuum conditions, respectively (Table 2). Treatments under vacuum conditions had lower emergence of $F_{1}$

Table 2. Mortality and adult emergence $\left(\mathrm{F}_{1}\right)$ of Sitophilus zeamais fed with maize treated with Peumus boldus powder alone and mixed with lime at proportions of $0: 100,50: 50,60: 40$, and 100:0 at concentrations of $1 \%$ and $2 \%(w / w)$ stored under and without vacuum conditions for $150 \mathrm{~d}$.

\begin{tabular}{|c|c|c|c|c|c|}
\hline \multirow[b]{2}{*}{ Formulation } & \multirow[b]{2}{*}{ Concentration } & \multicolumn{2}{|c|}{ Mortality } & \multicolumn{2}{|c|}{ Emergence $\left(\mathrm{F}_{1}\right)$} \\
\hline & & Vacuum & $\begin{array}{l}\text { Without } \\
\text { vacuum }\end{array}$ & Vacuum & $\begin{array}{l}\text { Without } \\
\text { vacuum }\end{array}$ \\
\hline$(\%: \%)^{1}$ & & & $\%$ & & \\
\hline $0: 100$ & 1.0 & $69.5 \mathrm{Ab}$ & $44.5 \mathrm{Ab}$ & 44.4Aa & $94.0 \mathrm{Aa}$ \\
\hline $0: 100$ & 2.0 & $72.9 \mathrm{Ab}$ & $49.5 \mathrm{Ab}$ & $11.1 \mathrm{Ba}$ & $98.8 \mathrm{Aa}$ \\
\hline $50: 50$ & 1.0 & $100.0 \mathrm{Aa}$ & 85.9Aa & $22.2 \mathrm{Aa}$ & $3.6 \mathrm{Ab}$ \\
\hline $50: 50$ & 2.0 & $100.0 \mathrm{Aa}$ & $100.0 \mathrm{Aa}$ & $0.0 \mathrm{Aa}$ & $0.0 \mathrm{Ab}$ \\
\hline $60: 40$ & 1.0 & $100.0 \mathrm{Aa}$ & $47.8 \mathrm{Bb}$ & $33.3 \mathrm{Aa}$ & 60.7Aab \\
\hline $60: 40$ & 2.0 & $100.0 \mathrm{Aa}$ & $95.8 \mathrm{Aa}$ & $0.0 \mathrm{Aa}$ & $1.2 \mathrm{Ab}$ \\
\hline 100:0 & 1.0 & $100.0 \mathrm{Aa}$ & $51.7 \mathrm{Bb}$ & $0.0 \mathrm{Aa}$ & 44.0Aab \\
\hline $100: 0$ & 2.0 & $100.0 \mathrm{Aa}$ & 89.9Aa & 11.1Aa & $3.6 \mathrm{Ab}$ \\
\hline
\end{tabular}

${ }^{1}$ Ratio boldo:lime (\%:\%).

Different uppercase letters indicate significant differences between columns for each treatment and lower-case letters indicate significant differences between rows for each type of package (under vacuum/ without vacuum) according to Tukey's test $(\mathrm{P} \leq 0.05)$. adult insects than treatments without vacuum conditions; a higher mortality-lower emergence trend was observed. These results agree with Silva et al. (2004), Pérez et al. (2007), and Cruzat et al. (2009), who concluded that higher concentrations of powder led to a higher mortality level and lower $F_{1}$ adult emergence. Treatments stored under vacuum conditions did not have any significant differences in $F_{1}$ emergence. In the case of treatments without vacuum conditions, those formulated with a higher concentration of $P$. boldus powder showed a lower $\mathrm{F}_{1}$, which coincided with data reported by Silva et al. $(2005 ; 2006)$ and BustosFigueroa et al. (2009), this is perhaps achieved by reducing the oviposition rate or impeding male and female encounter and then avoiding copula.

Grain weight loss and germination. Grain weight loss did not show any significant differences between types of storage. Losses under and without vacuum conditions were $0.72 \%$ and $0.67 \%$, respectively (Table 3 ). Treatments 50:50 and 100:0 at 1.0\% were the only ones significantly different from the control (Table 4). Our results are similar to those found by Silva et al. (2003a) and Cruzat et al. (2009), who observed weight losses above $1.0 \%$ at concentrations of $1.0 \%$ and $2.0 \%(\mathrm{w} / \mathrm{w})$ with boldus powder and lime used singly. The lower weight loss may be due to high mortality produced by treatments, which then reduced grain damage.

Treatments with $P$. boldus powder used alone or mixed with lime at both storage conditions did not affect significantly maize germination (Tables 3 and 4). Percentage germination was $96.95 \%$ and $95.13 \%$ under and without vacuum conditions, respectively.

Table 3. Grain weight loss and germination of maize infested with adults of Sitophilus zeamais stored under and without vacuum conditions for $150 \mathrm{~d}$.

\begin{tabular}{lcc}
\hline & Germination & Weight loss \\
\hline & $\%$ & $\mathrm{~g}$ \\
Under vacuum & $96.95 \mathrm{a}$ & $0.72 \mathrm{a}$ \\
Without vacuum & $95.13 \mathrm{a}$ & $0.67 \mathrm{a}$ \\
\hline
\end{tabular}

Different lower-case letters indicate significant differences between columns for each type of package (under vacuum/without vacuum) according to Tukey's test $(\mathrm{P} \leq 0.05)$.

Table 4. Grain weight loss and germination of maize treated with Peumus boldus powder alone and mixed with lime at proportions of 0:100, 50:50, 60:40, and 100:0 at concentrations of $1 \%$ and $2 \%(\mathrm{w} / \mathrm{w})$.

\begin{tabular}{lccc}
\hline Formulation & Concentration & Weight loss & Germination \\
\hline$(\%: \%)^{1}$ & -- & $1.50 \mathrm{a}$ & -- \\
Control $(0: 0)$ & 1.0 & $0.39 \mathrm{ab}$ & $95.56 \mathrm{a}$ \\
$0: 100$ & 2.0 & $0.67 \mathrm{ab}$ & $97.23 \mathrm{a}$ \\
$0: 100$ & 1.0 & $0.41 \mathrm{~b}$ & $93.34 \mathrm{a}$ \\
$50: 50$ & 2.0 & $0.93 \mathrm{ab}$ & $96.67 \mathrm{a}$ \\
$50: 50$ & 1.0 & $0.68 \mathrm{ab}$ & $96.11 \mathrm{a}$ \\
$60: 40$ & 2.0 & $0.66 \mathrm{ab}$ & $94.45 \mathrm{a}$ \\
$60: 40$ & 1.0 & $0.34 \mathrm{~b}$ & $97.78 \mathrm{a}$ \\
$100: 0$ & 2.0 & $0.75 \mathrm{ab}$ & $97.23 \mathrm{a}$ \\
$100: 0$ & & &
\end{tabular}

${ }^{1}$ Ratio boldus:lime (\%:\%).

Different lower-case letters indicate significant differences between formulations according to Tukey's test $(\mathrm{P} \leq 0.05)$. 
All treatments show germination percentage $>90 \%$, which agrees with data reported by Pizarro et al. (2013). However, our results disagree with Silva et al. (2003b) and Pérez et al. (2007), whose values did not exceed $75 \%$ germination at concentrations of $1.0 \%$ and $2.0 \%$ $(\mathrm{w} / \mathrm{w})$ and concluded that germination values decrease if powder concentration increases. This may be due to the time of year when plant material was field-collected since bioactivity of $P$. boldus foliage varies between seasons (Pérez et al., 2007); it is possible that the chemical compound that affects germination is absent or has a lower concentration in January, which was our collection date. The higher germination values obtained (> 90\%) comply with the requirement for export seeds (González, 1995); thus, this increases the possibility of using more effective treatments to protect grain and seed.

Repellent effect. The only treatment that did not show repellent effect was lime used alone (0:100) at 2.0\% (w/w) stored without vacuum conditions (Table 5). The rest of the treatments showed a repellency index $<1$, which, according to Mazzoneto and Vendramim (2003), classifies as repellent activity. Results match those found by Betancur et al. (2010) and Nuñez et al. (2010), who evaluated essential oil and boldus powder at concentrations of $1.0 \%$ and $2.0 \%$ and reported a repellency index of 0.45 and 0.18 for oil and powder, respectively; both values are similar to our research results.

Fumigant effect. Treatments 50:50 (1.0\% and 2.0\%), 60:40 (2.0\%), and 100:0 (1.0\% and 2.0\%) stored under vacuum conditions showed significantly higher mortality than fumigants as compared with treatments without vacuum conditions (Table 6). However, the highest mortality was obtained with boldus used alone (100:0) with $86.6 \%$ and $93.3 \%$ dead insects at concentrations of $1.0 \%$ and $2.0 \%$, respectively. These results agree with Nuñez et al. (2010), who reported the highest mortality in the same treatments but with values just over $47 \%$. Treatments stored without vacuum conditions did not surpass $10 \%$ of mortality, which may be due to degradation of plant compounds by oxygen present in the bags (Morales and García, 2000).

Table 5. Repellent effect of Peumus boldus powder alone or mixed with lime against adults of Sitophilus zeamais at proportions of 0:100, $50: 50,60: 40$, and 100:0 and concentrations of $1.0 \%$ and $2.0 \%(w / w)$ stored under and without vacuum conditions for $150 \mathrm{~d}$.

\begin{tabular}{lccc}
\hline Formulation & Concentration & $\begin{array}{c}\text { RI } \\
\text { Under vacuum }\end{array}$ & $\begin{array}{c}\text { RI } \\
\text { Without vacuum }\end{array}$ \\
\hline$(\%: \%)^{1}$ & $\%$ & & \\
$0: 100$ & 1.0 & 0.25 & 0.41 \\
$0: 100$ & 2.0 & 0.43 & 1.03 \\
$50: 50$ & 1.0 & 0.32 & 0.49 \\
$50: 50$ & 2.0 & 0.42 & 0.47 \\
$60: 40$ & 1.0 & 0.68 & 0.39 \\
$60: 40$ & 2.0 & 0.34 & 0.32 \\
$100: 0$ & 1.0 & 0.25 & 0.37 \\
$100: 0$ & 2.0 & 0.27 & 0.24 \\
\hline
\end{tabular}

${ }^{1}$ Ratio boldus:lime (\%:\%).

RI: Repellency index ( $>1$ attracting; = 1 neutral; $<1$ repellent).
Table 6. Toxicity against adults of Sitophilus zeamais by the fumigant effect of Peumus boldus powder alone or mixed with lime at proportions of $0: 100,50: 50,60: 40$, and 100:0 and concentrations of $1.0 \%$ and $2.0 \%(w / w)$ stored under and without vacuum conditions for $150 \mathrm{~d}$.

\begin{tabular}{|c|c|c|c|}
\hline Formulation & Concentration & $\begin{array}{c}\text { Mortality } \\
\text { Under vacuum }\end{array}$ & $\begin{array}{c}\text { Mortality } \\
\text { Without vacuum }\end{array}$ \\
\hline$(\%: \%)^{1}$ & & $\%-$ & \\
\hline $0: 100$ & 1.0 & $3.33 \mathrm{Ad}$ & $0.0 \mathrm{Aa}$ \\
\hline $0: 100$ & 2.0 & 3.33Ad & $0.0 \mathrm{Aa}$ \\
\hline $50: 50$ & 1.0 & $23.30 \mathrm{Ac}$ & $0.0 \mathrm{Ba}$ \\
\hline $50: 50$ & 2.0 & 63.30Abc & $3.33 \mathrm{Ba}$ \\
\hline $60: 40$ & 1.0 & $10.00 \mathrm{Ad}$ & $0.0 \mathrm{Aa}$ \\
\hline $60: 40$ & 2.0 & $40.00 \mathrm{Ac}$ & $3.33 \mathrm{Ba}$ \\
\hline $100: 0$ & 1.0 & 86.60Aab & $6.66 \mathrm{Ba}$ \\
\hline 100:0 & 2.0 & 93.30Aa & 3.33Ba \\
\hline
\end{tabular}

${ }^{1}$ Ratio boldus:lime (\%:\%).

Different uppercase letters indicate significant differences between columns for each treatment and lower-case letters indicate significant differences between rows for each type of package (under vacuum/ without vacuum), according to Tukey's test ( $\mathrm{P} \leq 0.05)$.

\section{CONCLUSIONS}

Vacuum storage extends insecticidal activity by $150 \mathrm{~d}$ as a contact insecticide against adult and immature Sitophilus zeamais as well as a repellent effect against adults. There was no impact on maize germination by the natural grain protector produced with Peumus boldus foliage powder mixed with lime.

\section{ACKNOWLEDGEMENTS}

The authors thank Carmen Herrera-Rodríguez, Carolina Ramírez-Mendoza, and Itzel Becerra-Morales of the Department of Agricultural Parasitology, Autonomous University of Chapingo in Mexico, and Carolina Sepulveda Campos from the Laboratory of Entomology, Faculty of Agronomy, Universidad de Concepción in Chile for their technical support.

\section{LITERATURE CITED}

Abbott, W.S. 1925. A method of computing the effectiveness of an insecticide. Journal of Economic Entomology 18:265-267.

Balzarini, M.G., L. González, M. Tablada, F. Casanoves, J.A. Di Rienzo, y C.W. Robledo. 2008. InfoStat: software estadístico: Manual del usuario. Versión 2008. Universidad de Córdoba. Editorial Brujas, Córdoba, Argentina.

Betancur, J., G. Silva, J. Rodríguez, S. Fischer, and N. Zapata. 2010. Insecticidal activity of Peumus boldus Molina essential oil against Sitophilus zeamais Motschulsky. Chilean Journal of Agricultural Research 70:399-407.

Bustos-Figueroa, G., F. Osses-Ruiz, G. Silva-Aguayo, M. TapiaVargas, R. Hepp-Gallo, and J. Rodríguez-Maciel. 2009. Insecticidal properties of Peumus boldus Molina powder used alone and mixed with lime against Sitophilus zeamais Motschulsky (Coleoptera: Curculionidae). Chilean Journal of Agricultural Research 69:350-355.

Cruzat, M., G. Silva, H. Serri, y R. Hepp. 2009. Protección de ocho cultivares de trigo con polvo de Peumus boldus Molina contra Sitophilus zeamais Motschulsky. Idesia 27:39-46.

FAO. 1993. El maíz en la nutrición humana. Colección FAO Alimentación y Nutrición $\mathrm{N}^{\circ} 25$. FAO, Rome, Italy. Available at http://www.fao.org/docrep/t0395s/t0395s00.htm (accessed May 2013). 
García-Lara, S., D.J. Bergvinson, A.J. Burt, A.I. Ramputh, D.M. Diaz-Pontones, and J.T. Arnason. 2004. The role of pericarp cell wall components in maize weevil resistance. Crop Science 44:1546-1552.

González, U. 1995. El maíz y su conservación. Trillas, México D.F., México.

Halstead, D. 1963. External sex differences in stored-products Coleoptera. Bulletin of Entomological Research 54:119-134.

Larraín, P. 1994. Manejo integrado de plagas en granos almacenados: alternativas para pequeños agricultores. Investigación y Progreso Agropecuario La Platina 81:10-16.

Makanjuola, WA. 1989. Evaluation of extracts of neem (Azadirachta indica A. Juss.) for the control of some stored product pests. Journal of Stored Products Research 25:231-237.

Malik, M.M., and N. Mujtaba. 1984. Screening of some indigenous plants as repellents or antifeedants for stored grain insects. Journal of Stored Products Research 20:41-44.

Mazzonetto, F., e J. Vendramim. 2003. Efeito de pós de origem vegetal sobre Acanthoscelides obtectus (Say) (Coleoptera: Bruchidae) em feijao armazenado. Neotropical Entomology 32:145-149.

Morales, L., y C. García. 2000. Metodología para la evaluación del potencial insecticida de especies forestales. Revista Facultad Nacional de Agronomía, Medellín 53:787-800.

Nuñez, P., G. Silva, M. Tapia, R. Hepp, J. Rodríguez-Maciel, y A. Lagunes-Tejeda. 2010. Toxicidad de polvos de follaje de paico (Chenopodium ambrosioides L.) y boldo (Peumus boldus M.) solos y en mezcla con carbonato de calcio sobre el gorgojo del maíz (Sitophilus zeamais Motschulsky). Agro-Ciencia 26:71-80.

Páez, A., A. Lagunes, J. Carrillo, y J. Rodríguez. 1990. Polvos vegetales y materiales inertes para el combate del gorgojo Sitophilus zeamais (Coleoptera: Curculionidae) en maíz almacenado. Agrociencia (México) 1:35-46.

Pereira, C.J., E.J.G. Pereira, E.M.G. Cordeiro, T.M.C. Della Lucia, M.R. Tótola, and R.N.C. Guedes. 2009. Organophosphate resistance in the maize weevil Sitophilus zeamais: Magnitude and behavior. Crop Protection 28:168-173.

Pérez, F., G. Silva, M. Tapia, y R. Hepp. 2007. Variación anual de las propiedades insecticidas de Peumus boldus sobre Sitophilus zeamais. Pesquisa Agropecuaria Brasileira 42:633-639.

Pimentel, M.A.G., L.R.D.A. Faroni, R.N.C. Guedes, A.H. Sousa, and M.R. Tótola. 2009. Phophine resistance in Brazilian populations of Sitophilus zeamais Motschulsky (Coleoptera: Curculionidae). Journal of Stored Products Research 45:71-74.

Pizarro, D., G., Silva, M. Tapia, J.C. Rodríguez, A. Urbina, A. Lagunes, et al.2013. Actividad insecticida del polvo Peumus boldus Molina (Monimiaceae) contra Sitophilus zeamais Motschulsky (Coleoptera: Curculionidae). Boletín Latinoamericano y del Caribe de Plantas Medicinales y Aromáticas (BLACPMA) 12:420-430.

Procópio, S., J. Vendramin, J. Ribeiro, e J. dos Santos. 2003. Bioatividade de diversos pós de origem vegetal em relaçao a Sitophilus zeamais Mots. (Coleoptera: Curculionidae). Ciência e Agrotecnología 27:1231-1236.
Ribeiro, B.M., R.N.C. Guedes, E.E. Oliveira, and J.P. Santos. 2003. Insecticide resistance and synergism in Brazilian populations of Sitophilus zeamais (Coleoptera: Curculiondae). Journal of Stored Products Research 39:21-31.

Silva, G., P. González, R. Hepp, y P. Casals. 2004. Control de Sitophilus zeamais Motschulsky con polvos inertes. Agrociencia (México) 38:529-536.

Silva, G., R. Hepp, M. Tapia, P. Casals, G. Bustos, y F. Osses. 2006. Evaluación de boldo (Peumus boldus Molina) y cal para el control de Sitophilus zeamais Motschulsky. Agrociencia (México) 40:219-228.

Silva, G., A. Lagunes, y J. Rodríguez. 2003a. Control de Sitophilus zeamais (Coleoptera: Curculionidae) con polvos vegetales solos y en mezcla con carbonato de calcio en maíz almacenado. Ciencia e Investigación Agraria 30:153-160.

Silva, G., O. Orrego, R. Hepp, y M. Tapia. 2005. Búsqueda de plantas con propiedades insecticidas para el control de Sitophilus zeamais en maíz almacenado. Pesquisa Agropecuaria Brasileira 40:11-17.

Silva, G., D. Pizarro, P. Casals, y M. Berti. 2003b. Evaluación de plantas medicinales en polvo para el control de Sitophilus zeamais Motschulsky en maíz almacenado. Revista Brasileira de Agrociência 9:383-388.

Silva-Aguayo, G., J. Rodríguez-Maciel, A. Lagunes-Tejeda, C. Llanderal-Cázares, R. Alatorre-Rosas, A.M. Shelton, et al. 2010. Bioactivity of boldo (Peumus boldus Molina) (Laurales: Monimiaceae) on Spodoptera frugiperda (J.E. Smith) and Helicoverpa zea (Boddie) (Lepidoptera: Noctuidae). Southwestern Entomologist 35:215-231.

Tavares, M., e J. Vendramim. 2005. Bioatividade da erva-de-santamaria, Chenopodium ambrosioides L., sobre Sitophilus zeamais Mots. (Coleoptera: Curculionidae). Neotropical Entomology 34:319-323.

USDA. 2000. Economic implications of the methyl bromide phaseout. Agriculture Information Bulletin nr 756. 12 p. Available at http://www.desertking.com/index.cfm/feature/58_23/banningof-methyl-bromide.cfm (accessed May 2013).

Vogel, H., I. Razmilic, y U. Doll. 1997. Contenido de aceite esencial y alcaloides en diferentes poblaciones de boldo (Peumus boldus Mol.) Ciencia e Investigación Agraria 24:1-6.

Weaver, D., and B. Subramanyam. 2000. Botanicals. p. 303-320. In Subramanyan, B., and D.W. Hagstrum (eds.) Alternatives to pesticides in stored product IPM. Kluwer Academics Publishers, Boston, Massachusetts, USA.

White, N.D.G., and J.G. Leesch. 1996. Chemical control. p. 287 330. In Subramanyan, B., and D.W. Hagstrum (eds.) Integrated management of insects in stored products. Marcel Dekker, New York, USA.

Zapata, N., F. Budia, G. Silva, E. Viñuela, y P. Medina. 2006 Actividad antialimentaria de Maytenus boaria Mol., Peumus boldus Mol. y Quillaja saponaria Mol. sobre Spodoptera littoralis Boisd. Boletín Sanidad Vegetal Plagas 32:125-135. 